\title{
HISTOLOGICAL AND IMMUNOHISTOCHEMICAL STUDIES OF THE CORNEA OF SOME ANIMAL SPECIES; I. REAPPRAISAL OF CHOLINERGIC INNERVATION
} Elnasharty M. ${ }^{1}$, Marei $\mathrm{H}^{2}$, Abd El-Mohdy F. ${ }^{3}$, Mansour A. ${ }^{4}$ and Kimura $\mathrm{H}^{5}$

${ }^{1}$ Histology Department, Faculty of Veterinary Medicine, Alexandria UniversityDamanhur Branch, Elbostan, Beheira, Egypt.

${ }^{2}$ Cytology and Histology Department, Faculty of Veterinary Medicine, Mansoura University, Mansoura, Egypt.

${ }^{3}$ Histology Department, Faculty of Veterinary Medicine, Kafrelsheikh University, Kafrelsheikh, Egypt.

${ }^{4}$ Anatomy and Embryology Department, Faculty of Veterinary Medicine, Kafrelsheikh University, Kafrelsheikh, Egypt.

${ }^{5}$ Molecular Neuroscience Research Center, Shiga University of Medical Science, Otsu, Japan.

\section{ABSTRACT}

The corneas of rat, mouse and guinea pig were investigated using light and electron microscopy as well as immunohistochemistry. We, here, examined the cholinergic structures in the cornea by immunohistochemistry for choline acetyltransferase of the two forms, the alternative splice variant from choline acetyltransferase (ChAT) cDNA preferentially located in peripheral nerves ( $p C h A T)$ and the common type (cChAT). Positive staining for cChAT was found only in non-neuronal epithelial cells, while pChAT positive staining occurred exclusively in nerve fibers being distributed throughout the cornea. Such pChAT positive nerve axons were frequently smooth with few varicosities, except for their terminal swellings. The distribution pattern of $p C h A T$ positive nerves was compared with that of three neuropeptides known to be found in corneal nerves, including protein gene product 9.5 (PGP 
9.5), substance $P(S P)$ and calcitonin gene-related peptide (CGRP). The co-localization of pChAT with either of these neuropeptides has been assumed on the base of their great similarity in distribution pattern and closeness in their routes inside the cornea. From these results it is concluded that rat, mouse and guinea pig corneas have little morphological differences and have a remarkable non-neuronal cholinergic activity in their epithelium together with what can be suggested to be cholinergic nerves represented in the pChAT positive nerve fibers. The function of acetyl choline in the corneal epithelium and the possible origin and function of corneal cholinergic nerves has been discussed.

Key words: Cornea; innervation; acetylcholine; acetyltransferase; alternative splicing.

\section{INTRODUCTION}

The cornea is a unique portion of the outer, fibrous ocular tunic that is transparent and serves a refractive function while maintaining a mechanically tough and chemically impermeable barrier between the eye and the environment (Klyce and Beuerman, 1988).

The anterior surface of the mammalian cornea plays an important role in maintaining a smooth optical interface and consequently a sharp retinal image. The smooth surface is produced by a tear film, which adheres to a variety of microprojections, which increase the cell surface area, improve the absorbance of oxygen and nutrients and aid in the movement of metabolic products across the outer cell membrane. It meets its oxygen requirement largely from atmospheric air via the anterior corneal surface and most of its additional nutritional requirement from the aqueous humour via the posterior corneal surface (Klyce and Beuerman, 1988; Dellmann, 1993 and Bloom and Fawcett, 1994). 
The mechanical strength of the cornea is provided by its collagen matrix which requires the presence of mechanisms that regulate hydration to maintain transparency. For protection, the cornea is endowed with exquisitely sensitive nerves (Klyce and Beuerman, 1988). The transparent nature of the cornea and its importance in the visual pathway as the major refracting lens of the eye intrigued workers in many different disciplines, and their studies have added immeasurably to the understanding of the cornea in health and disease (Beuerman and Pedroza, 1996). The corneal epithelium, stroma, and endothelium of mammals have been the object of many histological studies and consequently there are divergent opinions regarding morphology and histochemistry (Waltman, 1981; Craig and Parry, 1981; Snyder et al., 1998; and Reim et al., 2001). It was studied in rabbit (Al-Dhaheri, 1995), in cat (Carrington, et al., 1987), in dog (Helper, 1989 and Gliger et al., 1991), in camel (Derbalah, 2001), and in domestic animals (Prince, et al., 1960; Gelatt, 1981; Oehme, 1988; Zurawski, et al., 1989; Dyce, et al., 1996; and Konsowa and Abd-Alaziz, 1999). Moreover, reviews of the structure of the cornea date back to the earliest days of electron microscopy (Klyce and Beuerman, 1988).

The mammalian cornea, one of the most richly innervated organs in the body, receives a sensory innervation from the trigeminal ganglion and a sympathetic innervation originate from small to moderate numbers of cells located in ipsilateral superior cervical ganglion (Marfurt et al., 1989).

Since no evidence is available for the presence of choline acetyltransferase which is the most reliable marker for cholinergic fibers or vesicular acetylcholine transporter, a recent marker for cholinergic nerve fibers. And the morphological detail of both non-neuronal and neuronal 
cholinergic structures in the cornea is far from total understanding. Therefore, we aimed at evaluating cholinergic innervation of the cornea by immunohistochemical staining methods for antiserum against the common type choline acetyltransferase enzyme (cChAT) and its splice variant of peripheral type (pChAT) and comparing the resultant data to those of the pan-neural marker protein gene product 9.5; (PGP 9.5), calcitonin gene-related peptide (CGRP), and substance P (SP). It is also proposed that to give more information about the morphological aspects, using light and electron microscopy, of the cornea of rat, mouse, and guinea pig.

\section{MATERIALS AND METHODS}

\section{Tissue preparation:}

Male Wistar rats, 250-350 gm, male ICR mice, 4 weeks old or more (adult), and male Hartley guinea pig, 450-550 gm were examined in this study. A total of (40) corneas from three different species were examined as follow; 20 rats, 10 mouse and 10 guinea pigs.

\section{Conventional Histology:}

For light and electron microscopical studies, the animals were sacrificed by decapitation and the corneas were obtained. For light microscope (LM) the corneas were fixed in formalin $10 \%$ and/or Bouin's solution for at least 24 hours. The samples were processed for paraffin technique as usual and 5-7 $\mu \mathrm{m}$-thick microtome sections were obtained and stained with hematoxylin and eosin, Mallory's Trichrome: for C.T., Periodic Acid Schiff's reaction and Best's carmine. 
Samples for electron microscopy (EM) were fixed in glutraldehyde $2.5 \%$ in phosphate buffer, $\mathrm{pH} 7.4$, for 24 hours, processed as usual using osmic acid and embedded in Epon. Ultrathin sections were cut using ultramicrotome and contrasted with uranyl acetate and lead acetate. The observations were carried out using Hitachi H-7500 TEM (Tokyo, Japan).

\section{Immunohistochemistry:}

For immunohistochemistry, under pentobarbital anesthesia (50-80 $\mathrm{mg} / \mathrm{kg}$, i. p.), each animal was perfused on crushed ice through the ascending aorta with $10 \mathrm{mM}$ phosphate-buffered saline (PBS; pH 7.4), followed by a fixative containing $4 \%$ paraformaldehyde in $0.1 \mathrm{M}$ phosphate buffer (PB; $\mathrm{pH}$ 7.4). The cornea together with the adhering corneoscleral limbus of approximately 1-2 mm wide were dissected out and immersed for 2 days in the same fixative at $4^{\circ} \mathrm{C}$, and then cryoprotected by replacing in $0.1 \mathrm{M} \mathrm{PB}$ containing $15 \%$ sucrose at $4^{\circ} \mathrm{C}$ for $24-48 \mathrm{hrs}$. Four radial slits were made with a sharp razor blade in the periphery of the tissues. This procedure produced a "cloverleaf" arrangement consisting of four wedge-shaped corneal segments joined at the center and parallel tangential 28 to $40 \mu \mathrm{m}$-thick sections were cut using a cryostat. The sequential serial tangential sections were collected separately in $0.1 \mathrm{M}$ PBS containing $0.3 \%$ Triton-X 100 (PBST). Twenty $\mu$ m-thick corneal cross sections were used for both cChAT and pChAT immunostaining.

Immunostaining was performed using the avidin-biotin complex (ABC) technique. Specificity, working dilution, and sources of the primary antibodies used in this work are summarized in table 1. Free floating tangential corneal sections were treated for 30 minutes with $0.3 \%$ hydrogen peroxide in $0.1 \mathrm{M}$ maleate buffer ( $\mathrm{pH} 6.0$ ) at 
room temperature to eliminate endogenous peroxidase activity, then incubated for a period indicated bellow with a primary antibody, for $1 \mathrm{~h}$ with biotinylated secondary antibodies of an appropriate species (diluted 1:2,000; Vector, USA) at room temperature, and for $1 \mathrm{~h}$ with avidin-biotinylated peroxidase complex (diluted 1:2,000; ABC Elite, Vector) at room temperature. With antibodies to pChAT and cChAT sections were incubated for 3-4 days at $4^{\circ} \mathrm{C}$, while with antibodies to PGP 9.5, CGRP and SP sections were reacted overnight at room temperature or for $2 \mathrm{hr}$ at $37^{\circ} \mathrm{C}$. Dilution of the reagents and washing sections between each step were done with PBST. Color was developed by treating the sections for $10 \mathrm{~min}$ with a mixture containing $0.02 \%$ 3,3'-diaminobenzidine, $0.0045 \%$ $\mathrm{H}_{2} \mathrm{O}_{2}$ and $0.3 \%$ nickel ammonium sulfate in $50 \mathrm{mM}$ Tris- $\mathrm{HCl}$ buffer ( $\mathrm{pH}$ 7.6). The stained sections were mounted on gelatincoated glass slides, dehydrated by alcohol, cleared by xylene, and cover-slipped by Entellan. Immunohistochemical controls, where each primary or secondary antiserum or the $\mathrm{ABC}$ reagent was omitted, gave no positive staining.

Table (1): Primary antibodies used.

\begin{tabular}{|c|c|c|c|c|}
\hline Primary Antibodies & Species & Type & Source & Dilution \\
\hline $\begin{array}{l}\text { Choline acetyltransferase of } \\
\text { peripheral type (pChAT) }\end{array}$ & Rabbit & Polyclonal & $\begin{array}{l}\text { Kind gift of } \mathrm{H} . \\
\text { Kimura }\end{array}$ & $1: 100,000$ \\
\hline $\begin{array}{l}\text { Choline acetyltransferase of } \\
\text { common type (cChAT) }\end{array}$ & Goat & Polyclonal & Chemicon, USA & $1: 500$ \\
\hline Protein gene product (PGP 9.5) & Mouse & Monoclonal & UltraClone, UK & $1: 2000$ \\
\hline $\begin{array}{l}\text { Calcitonin gene related peptide } \\
\text { (CGRP) }\end{array}$ & Goat & Polyclonal & Biogenesis, UK & $1: 5000$ \\
\hline Substance P (SP) & Guinea-pig & Polyclonal & Peninsula, USA & $1: 10000$ \\
\hline
\end{tabular}

Kafrelsheikh Vet. Med. J. Vol. 7 No. 1 (2009) 
To evaluate the overall feature of corneal innervation by pChAT, PGP 9.5, SP and CGRP, we made line drawing of stained nerve fibers in a quadrant of each tangential section using a camera lucida equipped on a light microscope (Olympus BH-2, Japan). Then, all the drawings in the same quadrant of 3 or 4 sections from the entire corneal layer were superimposed.

\section{Double fluorescence immunohistochemistry in the cornea:}

To study the colocalization of pChAT with that for PGP 9.5, CGRP and SP, corneal sections were double immunostained for pChAT and each of these markers using fluorescence-labeled secondary antibodies. The corneal sections were incubated overnight at room temperature with a mixture of pChAT antiserum plus an antibody either to PGP 9.5, CGRP or SP. After washing, the sections were reacted for 3-6 hours at room temperature with Alexa Fluor 594-conjugated donkey anti-rabbit IgG (for pChAT) mixed with either Alexa Fluor 488-conjugated goat anti-mouse IgG (for PGP 9.5), Alexa Fluor 488-conjugated donkey anti-goat IgG (for CGRP), or Alexa Fluor 488-conjugated goat anti-guinea pig IgG (for SP). All the reagents of Alexa Fluor 488 (Molecular Probes, USA) were used at dilution 1:2,000. Dilution of the reagents and washing tissue specimens between each step were done with PBS. After washing, the corneal sections were mounted on glass slides, cover-slipped with buffered glycerin, and observed under a confocal microscope (LSM 510, Carl Zeiss, Thornwood, NY). Final images were adjusted for brightness and contrast using Adobe Photoshop 6.0 (Adobe Systems, San Jose, CA). 


\section{RESULTS}

\section{Light microscopic observations:}

The cornea was covered by stratified squamous non-keratinized epithelium of 4-6 layers in rat (Fig. 1A) and mouse (Fig. 1B), and 5-8 layers in guinea pig (Fig. 1C). Blood vessels restricted to the corneoscleral junction except in guinea pig which had additional fine superficial blood vessels at the central cornea.

Mallory's trichrome stain revealed that the cornea of the three examined species composed largely from connective tissue stroma namely collagen fibres. These collagen fibres arranged into bundles formed neatly organized lamellae ran parallel to the corneal surface. The second component of the corneal stroma was the flattened keratocytes represented in the elongated nuclei those arranged between the collagen lamellae and parallel to the corneal surface without preferential localization between anterior and posterior stroma (Fig. 1D).Using the PAS technique, the corneal epithelium showed positive reaction that was also observed in both subepithelial basement membrane and posterior limiting membrane (Fig. 1E). Best's carmine stain, revealed the presence of cytoplasmic glycogen granules inside the corneal epithelium (Fig. 1F).

\section{Electron microscopic observation:}

Using the electron microscopy, the obtained results of the corneal epithelium confirmed the LM observations that the cornea was covered by stratified squamous epithelium of 4-6 layers in rat 
and mouse (Fig. 2A) and 6-8 layers in guinea pig (Fig. 2B). Generally, the corneal epithelial cells usually had a fine granular and fibrillar cytoplasm, a relatively few organelles and large amount of glycogen particles. The surface structures were composed of microvilli and interspersed among them are broader ridges; microplicae thickened with rich glycoclyx (Fig. 2C). Light and dark appearing superficial cells are distinguished by transmission electron microscopy depending upon the electron reflex or light shades from the cytoplasm (Fig. 2D).

\section{Immunohistochemical observation:}

Reaction products positive for cChAT appeared to be confined in the cytoplasm of corneal epithelial cells only with no neuronal elements in the cornea (Fig. 3A).

The present immunohistochemical study has demonstrated that the cornea is richly innervated by nerve fibers positive for pChAT. These pChAT positive nerves appeared to enter the cornea via the corneoscleral limbus mainly at the deep corneal stroma. At the chamber angle in the deep stroma close to the limbus pChAT positive smooth fibres with few varicosities were seen to form a series of nerve bundles extending centripetally (Fig. 3B). At the limbus, networks of intensely stained pChAT positive fibers ran parallel to corneal peripheral edges. From the networks, fine pChAT positive fibers were ramified repeatedly into the inner pericorneal zone of the limbus, where some pChAT positive fibers seemed to locate near vascular elements of the superficial limbal 
arcades (Fig. 3C). A more complex network of thick- and thindiameter pChAT immunoreactive axons was seen in the superficial corneal stroma of guinea pig at the inner pericorneal zone (Fig. $3 \mathrm{D})$. Figure $3 \mathrm{E}$ shows pChAT staining in a very thin tangential section of the epithelial cell layer. Here within the basal epithelial layer, many pChAT axons shaped unique parallel pre-terminal varicosities or boutons known as "epithelial leashes". Most axonal endings were tipped by a single conspicuous, bulbous terminal expansion (Inset of Fig. 3E). In guinea pig, the subepithelial leashes followed irregular directions and trajectories, especially at the peripheral cornea (Fig. 3F)

\section{Immunohistochemistry for PGP 9.5, CGRP, and SP in rat cornea:}

In agreement with previous reports (Marfurt et al., 1998 and 2001), nerve fibers positive for PGP 9.5, SP and CGRP were detected in the corneoscleral limbus, corneal stroma and corneal epithelium of examined animals. The distribution pattern of each of these positive fibers resembled closely to that of pChAT positive nerves, though varying in density (Fig. 4). Figure 5 shows confocal images of a corneal tangential section stained doubly for pChAT and CGRP. In every part of the cornea, fibres stained for pChAT ran closely to, or appeared identical with, those for the other markers. Nerve fibres positive for CGRP showed dotty puncta or varicose whereas most pChAT positive nerves were always smooth in shape (Inset of Fig. 5). Similar results were obtained in sections doubly stained for pChAT and SP or PGP 9.5. 


\section{FIGURE LEGENDS}

Fig. (1): Photomicrograph showing the corneal epithelium of 4-6 layers in rat (A) and mouse (B) and of 6-8 layers in guinea pig (C) stained by H\&E. D; trichrome stain of the corneal stroma $(\mathrm{St}), \mathrm{E}$; PAS positive reaction in the corneal epithelium (Ep), and the thick Descemet's membrane (Des). F; Bests carmine stain showing the glycogen granules in the corneal epithelium. End; endothelium. X100 in A, B and C and X40 in D, E and F.

Fig. (2): Electron photomicrograph of the corneal epithelium of mouse showing stratified squamous epithelium of 4-6 layers (A) and guinea pig of 6-8 layers (B). The nuclei (N) of the corneal epithelium; the stroma (ST) with keratocytes (K). In (C) the superficial cells have both dark (D) and light (L) cells with tight junction (arrow) between the most superficial cells and desmosomal junctions (arrow heads) between them and the underlying cells. In (D) the microvilli (MV) and microplicae (MP) on the surface of superficial corneal epithelium with a thickened cell membrane covered by glycocalyx rich coat and the cytoplasm beneath them contained mats of microfilaments (MF). X2000 in A and B, X30,000 in C and X7500.

Fig. (3): Immunohistochemistry of the cChAT (cross section) of rat cornea showing positive reaction in the corneal epithelium (Ep) only (A) and pChAT (tangential section) positive nerve bundle in the corneal stroma (B). In (C) pChAT positive fibres run parallel to the corneal peripheral edge and around the blood vessels (BV). In (D) guinea pig cornea shows a dense meshwork of highly anastomosed pChAT positive fibres in the superficial layer of pericorneal zone. In (E) the rat subepithelial leashes of parallel fibres some of them ends in a bulbous expansion (arrow in the inset) while in guinea pig these leashes follow irregular directions $(\mathrm{F})$. X4 for $\mathrm{C}, \mathrm{X} 10$ for $\mathrm{A}, \mathrm{D}$ and $\mathrm{E}$, $\mathrm{X} 20$ for B and F and X100 for inset.

Fig. (4): The innervation of rat cornea with pChAT (A), PGP-9.5 (B), CGRP (C), and SP (D) positive fibers as traced by camera lucida drawing in a single quadrant of rat cornea. The distribution pattern throughout the cornea is almost similar while the density of innervation insignificantly varied between them

Fig. (5): Confocal images of a corneal tangential section stained doubly by immunofluorescence histochemistry for pChAT -red- (A), CGRP green- (B), and overlaid image for A and B (C). The two positive fibers appeared identical to each other and often run closely without apparent co-localization in all area of the rat cornea. Dotty puncta and fine varicose fibers appeared more frequently in case of CGRP than in case of pChAT positive ones (arrows in B and C). X20 for A, $\mathrm{B}$ and $\mathrm{C}$ and $\mathrm{X} 63$ for Inset. 
Histological And Immunohistochemical Studies Of The Cornea Of...
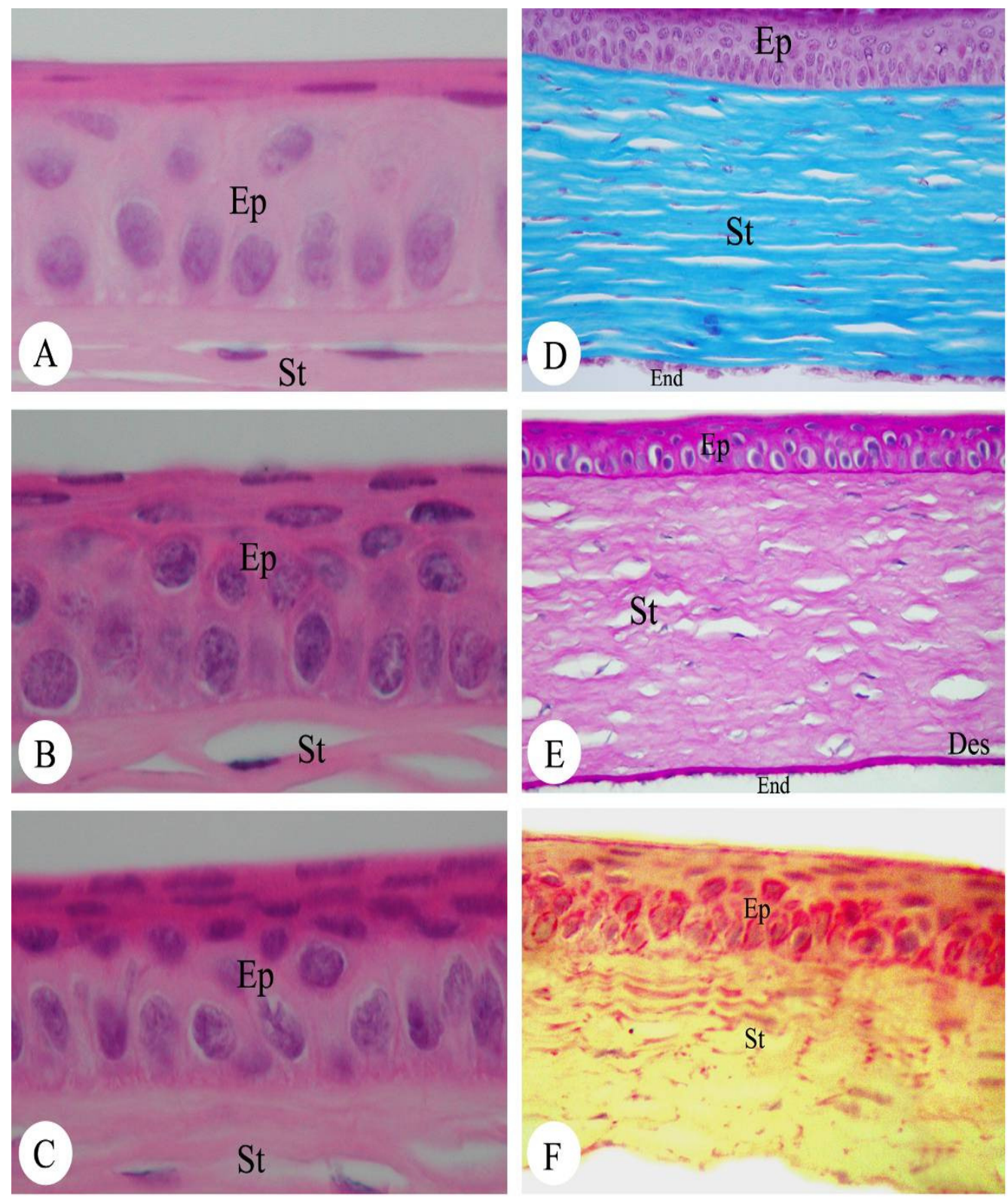

Fig. (1)

Kafrelsheikh Vet. Med. J. Vol. 7 No. 1 (2009) 
Elnasharty M. et al.,
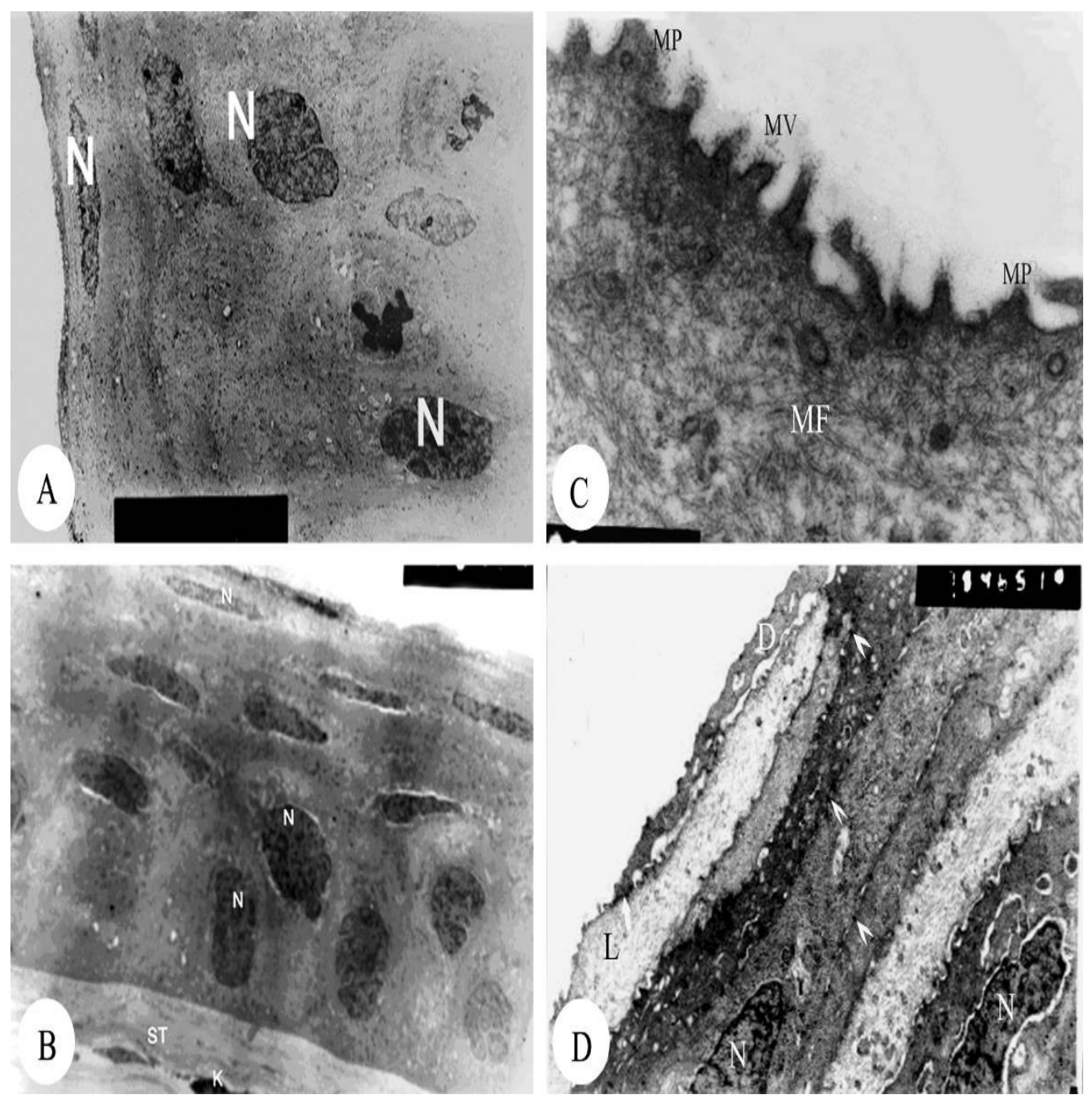

Fig. (2)

Kafrelsheikh Vet. Med. J. Vol. 7 No. 1 (2009) 

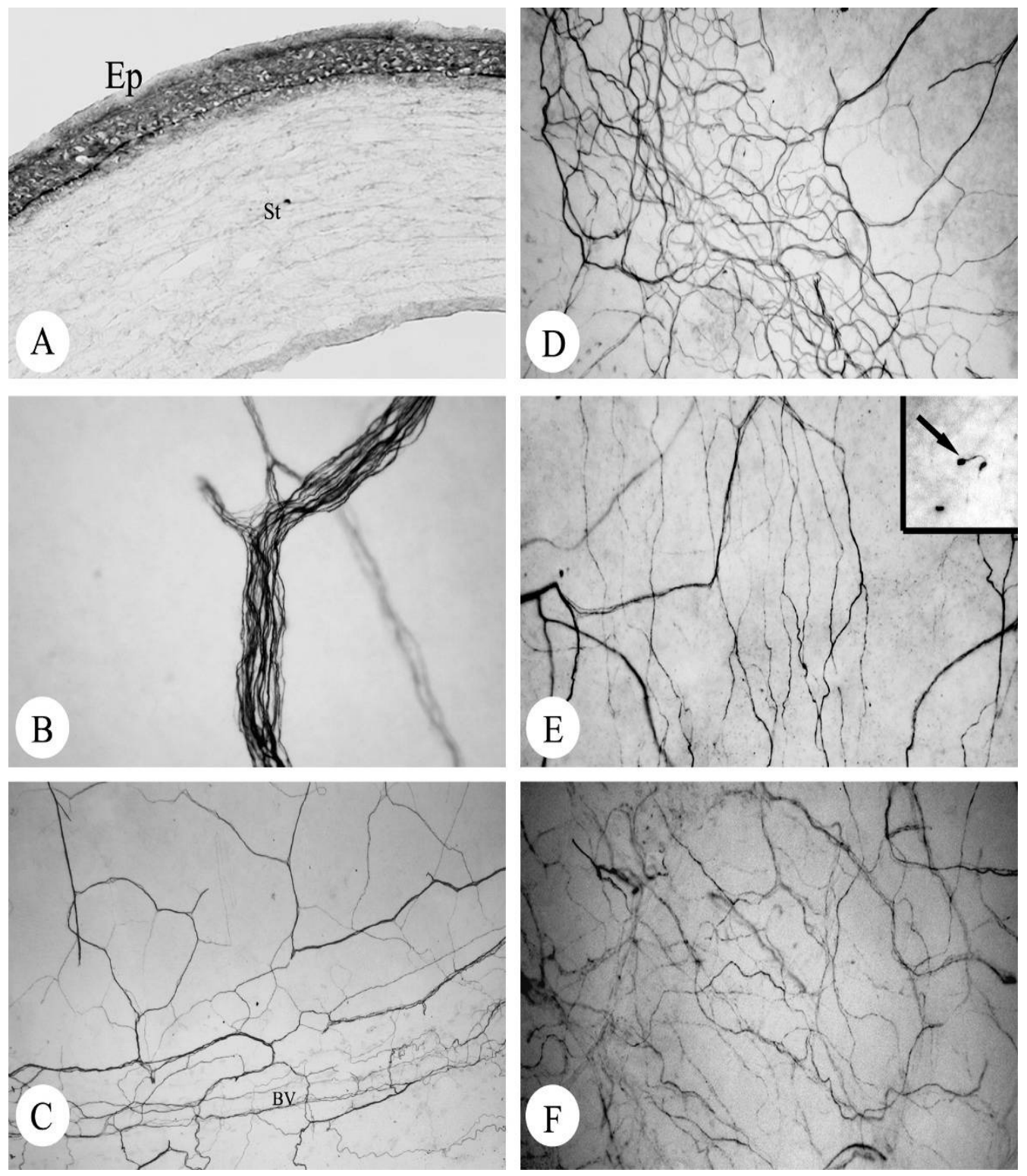

Fig. (3)

Kafrelsheikh Vet. Med. J. Vol. 7 No. 1 (2009) 

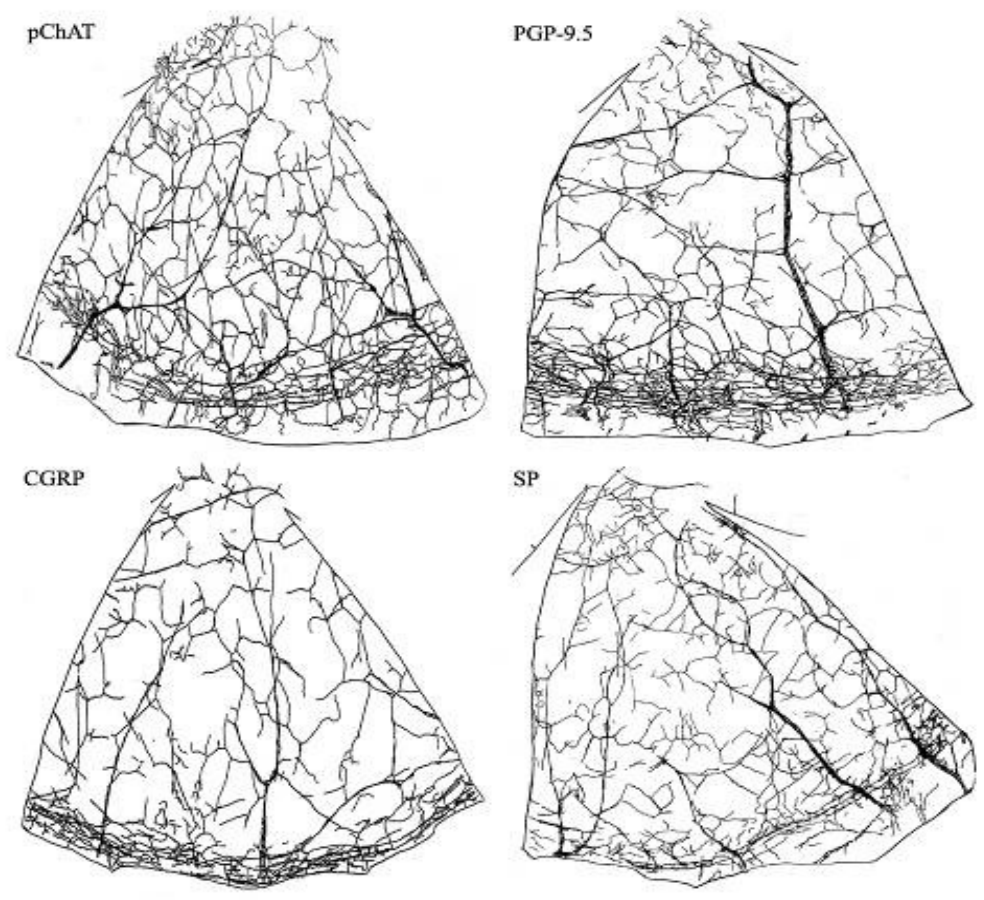

Fig. (4)
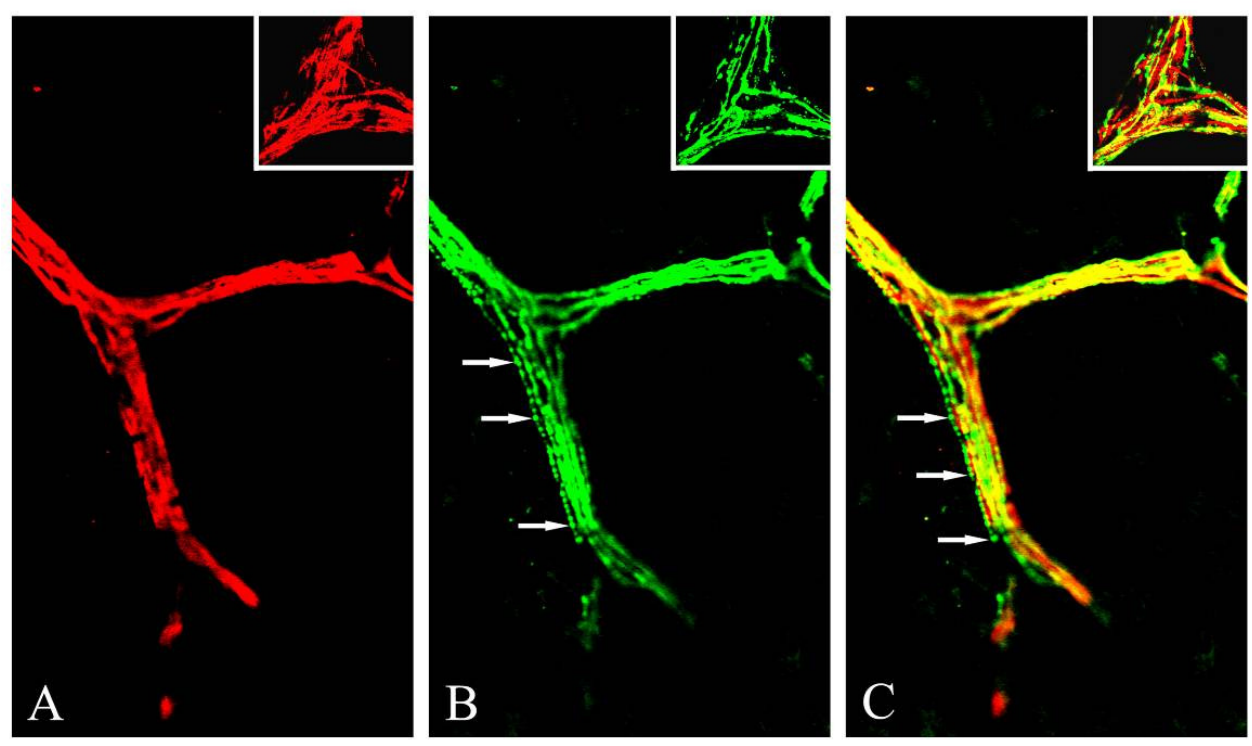

Fig. (5)

Kafrelsheikh Vet. Med. J. Vol. 7 No. 1 (2009) 


\section{DISCUSSION}

In the current study, the corneal epithelium was composed of 4-6 cell layers in both rat and mouse while it was composed of 6-8 cell layers in guinea pig cornea. This was in agreement with the result reported by Ehlers (1970b) in rat, mouse and guinea pig. Moreover, Ehlers (1970b), Doughty (1990a) and Jester et al., (1992) reported in rabbit that the corneal epithelium composed of 6-8 cell layers. In contrary, only Mastropasqua et al., (1998) mentioned that the rat corneal epithelium consisted of 12-15 cell layers. The presence of small blood vessels at the peripheral cornea may suggest less transparency; however more rapid healing after corneal injury at this region is more likely than in the central cornea which lacks such blood vessels (Dwyer et al., 1983). The demonstration of glycogen in the corneal epithelium in all the species investigated is concordant with previous investigations of large number of animals (Ehlers 1970a) and human corneas (Beuerman and Pedroza 1996). The abundance of PAS positive granules (glycogen) and the very few mitochondria reflects the importance of the anaerobic mode of metabolism and the energy production via glycolysis (Burkitt et al., 1994). The glycogen metabolism gives also water which can be considered as an additional source of fluid especially to the superficial cell layer to overcome dryness (Derbalah 2001).

Dark and light cells observed by TEM here were described by many investigators including Klyce and Beuerman (1988), Ringvold (1983), Doughty (1991), Smolin and Thoft (1994), and Beuerman and Pedroza (1996). Pfister (1973) postulated that, dark cells may be dark by virtue of 
density or length of the microvilli, the presence of more absorbed mucin, the nature of plasma membrane, or a combination of factors. Moreover, Smolin and Thoft (1994) and Doughty (1997) reported that the light cells are those which have most recently migrated to the epithelial surface while the dark cells are the "oldest" cells and the fewer microplicae they had indicating that they are about to desquamate.

The presence of microvilli and microplicae was in accordance with the result in mouse reported by Amemiya et al., (1980), Ringvold (1983), and Hazlett et al., (1984) and in rabbit reported by Doughty (1990 and 1996). They function in increasing the surface area of the superficial cells to maximize the absorbance of oxygen and nutrients, aid in movement of metabolic products across the outer cell membrane, assist in holding, stabilizing the tear film and so aid in maintaining the moisture of the epithelial surface (Cormack 1987; Weiss 1988; Beuerman and Pedroza 1996).

Since ChAT is the catalytic enzyme involved in the synthesis of ACh from choline and acetyl coenzyme A, the current result confirmed the presence of acetylcholine in the rat corneal epithelium. The presence of acetylcholine in the corneal epithelium has been well documented (von Brüke et al., 1949; Fitzgerald and Cooper, 1971; Grädinger et al., 1973; Howard et al., 1973; Mindel and Mittag, 1976; Pesin and Candia, 1982; and Gwin et al., 1979). Although our result showed that rat cornea had strong reactivity with the cChAT antibody, the ChAT activity was limited in the dog cornea (Gwin et., 1979) and little or not detectable in cat cornea (Mindel and Mittag, 1976). These differences 
could be due to species variations or different techniques applied. Although the role of the ACh in the corneal epithelium is unknown (Mindel and Mittag, 1976), a role in ion and water transport and corneal transparency (Stevenson and Wilson, 1975; and Pesin and Candia, 1982) or contribution to the pain associated with corneal abrasions has been suggested (Tanelian, 1991). Since cholinergic receptors are not detectable in the cornea (Olsen and Neufeld, 1979), Wilson and McKean (1986) suggested that, ACh probably has no function in the cornea itself and corneal epithelial ACh may affect a structure distant from its site of release.

Dense innervation of cornea with pChAT+ nerves using the splice variant of ChAT enzyme pChAT antibody introduced by Tooyama and Kimura (2000) were noticed for the first time and resembled greatly those of the other three markers used in current investigation; PGP-9.5, CGRP, and SP. All of them entered the cornea at the limbus in radial bundles arranged almost evenly around the corneal circumference. These bundles rapidly ascended across the stroma and branched dichotomously to terminate in the corneal epithelium. Similar patterns of distribution were previously described in the cornea of various mammalian species, including human, as reported by Tervo and Palkama (1978), Sasaoka et al., (1984) Terenghi et al. (1986), Chang-Ling (1989), Harris and Purves (1989), Ogilvy et al. (1991), Marfurt et al. (1993), Jones and Marfurt (1998), and Marfurt et al. (2001).

Lee et al.(1985),Kuwayama and Stone (1987), Uusitalo et al. (1989), and Ma et al. (2001) reported that the sensory markers CGRP and SP colocalize in the corneal nerves. In good agreement our doubly immunostained preparations indicated that $\mathrm{pChAT}+$ nerves were situated very close, 
if not co-localization, with those of PGP-9.5, CGRP, or SP+ nerves. Since both CGRP and SP are sensory markers, the pChAT+ fibres documented in the rat cornea may have the same origin; i.e. sensory. Nevertheless, in several studies, it has been hypothesized that sensory nerves not only serve an afferent role, but also have an efferent function in response to noxious stimuli, permitting sensory axon modulation of autonomic neuron activity and triggering of protecting reflexes, such as the ocular injury response (Beckers et al., 1993). A trophic role for corneal sensory nerves has been recognized on the basis of clinical and experimental observations (Jones and Marfurt, et al., 1993 and 1998). Recent investigations have suggested that sensory nerves play roles in corneal epithelial wound healing (Nishida et al., 1996; and Nakamura et al., 1997). So far, although true cholinergic nerves have not been demonstrated convincingly in the cornea yet, the presence of pChAT+ nerves in the rat cornea suggests the presence of cholinergic sensory neurons. The cholinergic nature of some primary sensory neurons especially of pChAT+ neurons was supported by previous results with Western blotting, RT-PCR and ChAT enzyme assay (Yasuhara et al., 2004 and Bellier and Kimura, 2007). Bellier and Kimura (2007) demonstrated acetylcholine synthesis by pChAT in the rat dorsal root ganglionic neurons and proposed a role of acetylcholine in neurotransmission of the primary sensory afferents. The functional roles of pChAT in the corneal nerves are unknown and need further investigations in the future. Moreover, the mechanism by which sensory nerves exert their functions is unclear; however, the release of axonally transported peptides or neurotransmitters has been proposed (Stone et al., 1987; and GarciaHirschfeld et al., 1994). 


\section{REFERENCES}

- Al-Dhaheri, S. M. M. (1995): Ultrastructural basis of corneal transparency and nutrition in rabbit. Thesis for master degree, Faculty of Medicine, Zag. Univ.

- Amemiya, T., Yoshida, H., Yoshida, M. and H. Kawaji (1980): Ultrastructures of the normal surface of the corneal epithelium of the heterozygous rhino mouse with special reference to so-called epithelial holes. Albrecht V Graefes Arch Klin Exp Ophthal 213:101107.

- Beckers, H. J., Klooster, J., Vrensen, G. F. and W. P. Lamers (1993): Substance $\mathrm{P}$ in rat corneal and iridal nerves: An ultrastructural immunohistochemical study. Ophthalmic Res 25:192-200.

- Bellier,JB and H. Kimura (2007): Acetylcholine synthesis by choline acetyltransferase of a peripheral type as demonstrated in adult rat dorsal root ganglion. J Neurochem. 101:1607-18

- Beuerman, R. W. and L. Pedroza (1996): Ultrastructure of the human cornea. Microsc Res Tech 33:320-335.

- Bloom, W. and D. W. Fawcett (1994): The Eye; Textbook of Histology; $12^{\text {th }}$ Ed. W. B. Saunders C., Philadelphia. Chapter 34, pp 872-882.

- Burkitt, A., Young, B. and W. Heath (1994): Special sense organs; Wheatear's Functional histology (Text Atlas). $4^{\text {th }}$ Ed. Churchill Livingstone, Longman Group UK, pp 380-405.

- Carrington, S. D., Alexander, R. A., Grocott, P. and I. Grierson (1987): The viscous layer overlying the corneal posterior epithelium of the domesticated cat. J Anat 153:77-92.

- Chang-Ling, T. (1989): Sensitivity and neural organization of the cat cornea. Invest Ophthalmol Vis Sci 30:1075-1082. 
- Cormack, D. H. (1987): Ham's Histology $9^{\text {th }}$ Ed. J. B. Lippincott Company, Philadelphia, London, Mexico City, New York, St. Louis, Sao Paulo, Sydney. 25:678-683.

- Craig, A. S. and D. A. Parry (1981): Collagen fibrils of the vertebrate corneal stroma. J Ultrastr Res 74:232-239.

- Dellmann, H. D. (1993): Eye. Textbook of Veterinary Histology. $4^{\text {th }}$ Edn. Lea and Febiger. Philadelphia, pp 313-325.

- Derbalah, A. E. M. (2001): Light and electron microscopical studies on the eye of one humped camel (Camelus Dromedarius). Thesis for master degree, Fac. Vet. Med., Alexandria Univ.

- Doughty, M. J. (1990): On the evaluation of the corneal epithelial surface by scanning electron microscopy. Optem Vis Sci 67:735-756.

- Doughty, M. J. (1990a): Analysis of areas and shapes of cells on the corneal surface of the albino rabbit by scanning electron microscopy. Cur Eye Res 9:295-306.

- Doughty, M. J. (1991): Scanning electron microscopy study of cell dimensions of rabbit corneal epithelium surface. Cornea 10:149-155.

- Doughty, M. J. (1996): Evidence for heterogeneity in a small squamous cell type ('light' cells) in the rabbit corneal epithelium. A scanning electron microscope study. Doc Ophthalmol 92:117-136.

- Doughty, M. J. (1997): Scanning electron microscopy study of the tarsal and orbital conjunctival surfaces compared to peripheral corneal epithelium in pigmented rabbits. Doc Ophthalmol 93:345-371.

- Dwyer,R.S.,Darougar,S. and M. A. Monnickendam (1983): Unusual features in the conjunctiva and cornea of the normal guinea pig: Clinical and histological studies. Br J Ophthalmol 67:737-741. 
- Dyce, K. M., Sack, W. O. and C. J. G. Wensing (1996): A textbook of Veterinary Anatomy $2^{\text {nd }}$ ed. W. B. Saunders Company, Philadelphia, London, Toronto. Chapter 9, pp 325-349.

- Ehlers, N. (1970a): Morphology and histochemistry of the corneal epithelium of mammals. Acta Anat 75:161-198.

- Ehlers, N. (1970b): Some morphological studies on the mammalian corneal epithelium. Acta Ophthalmol 48:820-828.

- Fitzgerald,G.G. and J. R. Cooper (1971): Acetylcholine as a possible sensory mediator in rabbit corneal epithelium. Biochem Pharmacol 20:2741-2478.

- Garcia-Hirschfeld, J., Lopez-Briones, L. G. and C. Belmonte (1994): Neurotrophic influences on corneal epithelial cells. Exp Eye Res 59:597-605.

- Gelatt, K. N. (1981): Veterinary Ophthalmology. Lea \& Febiger, Philadelphia. Chapter2, pp. 12-37.

- Gliger, B. C., Whitley, R. D., McLaughlin, S. A. Wright, J. C. and J. W. Drane (1991): Canine Corneal thickness measured by ultrasonic pachymetry. Am J Vet Res 52:1570-1572.

- Grädinger, M. C., Heimann, R. and R. Markstein (1973): Choline acetyltransferase in corneal epithelium. Exp Eye Res 15:395- 399.

- Gwin, R. M., Gelatt, K. N. and C. Y. Chiou (1979): Adrenergic and cholinergic innervation of the anterior segment of the normal and glaucomatous dog. Invest Ophthalmol Vis Sci 18:674-682.

- Gwin, R. M., Gelatt, K. N. and C. Y. Chiou (1979): Adrenergic and cholinergic innervation of the anterior segment of the normal and glaucomatous dog. Invest Ophthalmol Vis Sci 18:674-682. 
- Harris, L. W. and D. Purves (1989): Rapid remodeling of sensory ending in the corneas of living mice. J Neurosci 9:2210-2214.

- Hazlett, L. D., Wells, P. A. and R. S. Berk (1984): Scanning electron microscopy of the normal and experimentally, infected ocular surface. Scanning Electron Microscopy, III: 1379-1389.

- Helper, C. L. (1989): Magrane's canine ophthalmology $4^{\text {th }}$ ed. Lea \& Febiger, Philadelphia, London. Chapter 6, pp. 102-106.

- Howard,R.O.and W.S. Wilson (1972): Development of acetylcholine, choline acetyltransferase and acetylcholinesterase in rabbit corneal epithelium. Br J Pharmacol 46:567-568.

- Jester, J. V., Petroll, W. M., Garana, R. M. R., Lemp, M. A. and H. D. Cavanagh (1992): Comparison of in vivo and ex vivo cellular structure in rabbit eyes detected by tandem scanning microscopy. J Micros 165:169-181.

- Jones, M. A. and C. F. Marfurt (1998): Peptidergic innervation of the rat cornea. Exp Eye Res 66:421-435.

- Klyce, S. D. and R. W. Beuerman (1988): Structure and function of the cornea. In: The Cornea. (H. E. Kaufman, B. A. Barron, M. B. McDonald, and S. R. Waltman, eds). Churchill Livingstone, New York, pp. 3-54.

- Konsowa, M. and S. A. Abd-Alaziz (1999): Comparative anatomy and histology of the cornea in some domestic animals. Zag Univ Med J $5: 478-495$.

- Kuwayama, Y. and R. A. Stone (1987): Distinct substance P and calcitonin gene-related peptide immunoreactive nerves in the guinea pig eye. Invest Ophthalmol Vis Sci 28:1947-1954. 
- Lee,Y., Kawai, Y., Shiosaka, S., Takami, K., Kiyama, H., Hillyard, C. J., Girgis, S., MacIntyre, I., Emson, P. C. and M. Tohyama (1985): Coexistence of calcitonin gene-related peptide and substance P-like peptide in single cells of the trigeminal ganglion of the rat: immunohistochemical analysis. Brain Res 330:194-196.

- Ma, Q-P., Hill, R. and D. Sirinathsinghji (2001): Colocalization of CGRP with 5-HT 1B/1D receptors and substance $\mathrm{P}$ in trigeminal ganglion neurons in rats. Eur J Neurosci 13:2099-2104.

- Marfurt,C.F.,Ellis, L.C.and M.A.Jones(1993): Sensory and sympathetic nerve sprouting in the rat cornea following neonatal administration of Capsaicin. Somatos. Motor Res 10:337-398.

- Marfurt, C.F., Jones M. A. and K. Thrasher (1998): Parasympathetic innervation of the rat cornea. Exp Eye Res 66:437-448.

- Marfurt, C.F., Kingsley, R. E. and S. E. Echtenkamp (1989): Sensory and sympathetic innervation of the mammalian cornea. Invest Ophthalmol Vis Sci 30:461-472.

- Marfurt, C. F., Murphy, C. J. and J. L. Florczak (2001): Morphology and Neurochemistry of canine innervation. Invest Ophthalmol Vis Sci 42:2242-2251.

- Mastropasqua, L. Ciancaglini, M., Di Tano, G., Carpineto, P. Lobefalo, L., Bosco, D., Columbaro, M. and E. Falcieri (1998): Ultrastructural changes in the rat cornea after prolonged hypobaric hypoxia. J Submicrosc Cytol Pathol 30:285-293.

- Mindel, J. S. and T. W. Mittag (1976): Choline acetyltransferase in ocular tissues of rabbits, cats, cattle, and man. Invest Ophthalmol Vis Sci 15:808-814. 
- Nakamura,M.,Nishida,T.,Ofuji,K.,Reid,T. W., Mannis, M. J. and C. J. Murphy (1997): Synergistic effect of substance P with epidermal growth factor on epithelial migration in rabbit cornea. Exp Eye Res 65:321-329.

- Nishida, T., Nakamura, M., Ofuji, K., Reid T. W., Mannis, M. J. and C. J. Murphy (1996): Synergistic effect of substance P with insulinlike growth factor-1 on epithelial migration of the cornea. $\mathrm{J}$ cell Physiol 169:159-166.

- Oehme, F. W. (1988): Textbook of large animal surgery $2^{\text {nd }}$ ed. Lippincott, Williams and Wilkins Baltimore. Hong Kong, London, Sydney. pp, 623-660.

- Ogilvy, C. S., Silverberg, K. R. and L. F. Borges (1991): Sprouting of corneal sensory fibres in rats treated at birth with capsaicin. Invest Ophthalmol Vis Sci 32:112-121.

- Olsen, J. S. and A. H. Neufeld (1979): The rabbit cornea lacks cholinergic receptors. Invest Ophthalmol Vis Sci 18:1215-1225.

- Pesin,S.R. and O. A. Candia (1982): Acetylcholine concentration and its role in ionic transport by the corneal epithelium. Invest Ophthalmol Vis Sci 22:651-659.

- Pfister, R. R. (1973): The normal surface of corneal epithelium: a scanning electron microscopic study. Invest Ophthalmol 12:654-668.

- Prince, J. H., Diesem, C. D., Eglitis, I. and G. L. Ruskell (1960): Anatomy and Histology of the eye and orbit in domestic animals. Springfield, III, Charles Thomas.

- Reim, M., Schrage, N. F. and J. Becker (2001): Interactions between ocular surface fluid and cornea related to contact lenses. Eur $\mathbf{J}$ Ophthalmol 11:105-115. 
- Ringvold, A. (1983): Damage of the cornea epithelium caused by ultraviolet radiation. A scanning electron microscopic study in rabbit. Acta Ophthalmol 61:898-907.

- Sasaoka, A., Ishimoto, I., Kuwayama, Y., Sakiyama, T., Manabe R., Shiosaka,S., Inagaki, S. and M. Tohyama (1984): Overall distribution of substance $\mathrm{P}$ nerves in the rat cornea and their three-dimensional profiles. Invest Ophthalmol Vis Sci 25:351-6.

- Smolin, G.and R. A. Thoft (1994): The Cornea; Scientific Foundation and Clinical Practice, $3^{\text {rd }}$ Ed. Little, Brown and Company, Boston/ New York/Toronto/ London. Chapter 1 pp:3-17.

- Snyder, M. C., Bergmanson, J. P. G. and M. J. Doughty (1998): Keratocytes: no more the quiet cells. J Am Optom Assoc 69:180-186.

- Stevenson, R. W. and W. S. Wilson (1975): The effect of acetylcholine and eserine on the movement of $\mathrm{Na}^{+}$across the corneal epithelium. Exp Eye Res 21:235-244.

- Stone,R. A., McGlinn, A. M., and Y. Kuwayama (1987): Galanin-like immunoreactive nerves in the porcine eye. Exp Eye Res 46:457-461.

- Tanelian,D.L.(1991):Cholinergic activation of a population of corneal afferent nerves. Exp Brain Res 86:414-420.

- Terenghi, G., Zhang, S-Q., Unger, W. G. and J. M. Polak (1986): Morphological changes of sensory CGRP-immunoreactive and sympathetic nerves in peripheral tissues following chronic denervation. Histochem 86:89-95.

- Tervo, T. and A. Palkama (1978): Innervation of the rabbit cornea: a histochemical and electron-microscopic study. Acta Anat 102:164-175. 
- Tooyama, I. and H. Kimura (2000): An alternative splice variant of choline acetyltransferase is localized preferentially in peripheral nerve cells and fibres: Implication for a peripheral cholinergic marker. J Chem Neuroanat 17:217-226.

- Uusitalo, H., Krootila, K. and A. Palkama (1989). Calcitonin generelated peptide (CGRP) immunoreactive sensory nerves in the human and guinea pig uvea and cornea. Exp Eye Res 48:467-475.

- von Brüke,H. V., Hellauer,H. F. and K. Umrath (1949). Azetylcholinund Aneuringehalt der Hornhaut und seine Bezeihungen zur Nervenversorgung Opthalmologica 99:436-442.

- Waltman,S.E. (1981): Cornea and sclera. In Moses R. A., ed. Adler's Physiology of the Eye, $7^{\text {th }}$ ed. St. Louis: C.V. Mosby Co. Section 2, pp 48-67.

- Weiss, L. (1988): Cell and Tissue Biology. A Textbook of Histology, $6^{\text {th }}$ ed. Urban \& Schwarzenberg. Baltimore. Munich. pp 1072-1081.

- Wilson, W. S. and C. E. McKean (1986): Regional distribution of acetylcholine and associated enzymes and their regeneration in corneal epithelium. Exp Eye Res 43:235-242.

- Yasuhara, O., Aimi, Y., Shibano, A., Matsuo, A., Bellier, J-P., Park, M., Tooyama, I. and H. Kimura (2004): Innervation of rat iris by trigeminal and ciliary neurons expressing pChAT, a novel splice variant of choline acetyltransferase. J comp Neurol 472:232-245.

- Zurawski, C. A, Mac Carey, B. E., Van-Rij, G. and A. Fernandes (1989): Corneal biometrics of the rhesus monkey (Macaca mulatle). J Med Primatol 18:461-466. 